\title{
Effect of insulin-like growth factor I infusion on renal hypertrophy in experimental diabetes mellitus in rats
}

\author{
A. Flyvbjerg ${ }^{1}$, K. E. Bornfeldt ${ }^{2}$, H.Ørskov ${ }^{1}$ and H.J. Arnqvist ${ }^{3}$ \\ Institute of Experimental Clinical Research, University of Aarhus, Aarhus, Denmark and Departments of ${ }^{2}$ Pharmacology and \\ ${ }^{3}$ Internal Medicine, University of Linköping, Linköping, Sweden.
}

\begin{abstract}
Summary. Initial diabetic renal hypertrophy is preceded by a transient increase in kidney insulin-like growth factor I suggesting that insulin-like growth factor I may be implicated in diabetic kidney growth. The present study was undertaken to examine the effects of exogenous insulin-like growth factor I infusion on diabetic renal hypertrophy at a time when renal insulin-like growth factor I concentration had returned to normal and the initial steep kidney growth rate had diminished to a much slower rate. Groups of rats with diabetes duration of 5 days were infused s.c. for 4 subsequent days with equimolar concentrations of insulin-like growth factor I ( $36 \mathrm{nmol} /$ day) or insulin ( $35 \mathrm{nmol} / \mathrm{day})$. Insulin infusion lowered blood glucose to a normal level within 2 days and induced an average body-weight gain of $9.3 \pm 0.6 \mathrm{~g} /$ day. Insulin-like growth factor I infused diabetic rats maintained the original diabetic state with blood glucose levels comparable to those of $0.154 \mathrm{~mol} / \mathrm{l} \mathrm{NaCl}$-infused diabetic rats, but had nevertheless an average body-weight gain of $6.8 \pm 1.0 \mathrm{~g} /$ day while untreated diabetic rats had a lower body-weight gain amounting to $3.3 \pm 0.8 \mathrm{~g} /$ day $(p<0.01)$. The kidney weight at day 9 in untreated diabetic animals was about $25 \%$ greater than that of non-diabetic control animals, while in insulin-like growth factor I treated diabetic rats a further increase $(p<0.05)$ was
\end{abstract}

seen, amounting to $36 \%$ above control level. No increase was seen in the insulin-treated diabetic group. Whole kidney protein, RNA and DNA estimations indicated that, in $0.154 \mathrm{~mol} / \mathrm{l}$ $\mathrm{NaCl}$-infused diabetic animals, the kidney growth after 9 days constituted a mixture of cellular hypertrophy and hyperplasia while the excess kidney weight increase obtained in insulinlike growth factor I infused diabetic rats was due mainly to hypertrophy. The kidney content of immunoreactive insulinlike growth factor I at day 9 in insulin-like growth factor I infused diabetic rats was on average $85 \%$ greater than in $0.154 \mathrm{~mol} / \mathrm{l} \mathrm{NaCl}$-infused diabetic and non-diabetic control groups, while no differences were found in insulin-like growth factor I mRNA levels. In conclusion, insulin-like growth factor I administration initiated after 5 days of diabetes, with restoration of high kidney insulin-like growth factor I levels similar to those seen after 1-2 days of diabetes, accelerates renal growth, supporting the concept that the early kidney insulin-like growth factor I accumulation may be the stimulus for initial diabetic kidney hypertrophy.

Key words: Renal hypertrophy, insulin, insulin-like growth factor I, insulin-like growth factor I mRNA, streptozotocin diabetes, rat.
Renal hypertrophy is a characteristic feature of both experimental and human diabetes [1,2]. The first sign of kidney growth is an increase in total RNA as early as $36-48 \mathrm{~h}$ after induction of streptozotocin (STZ) diabetes mellitus in rats [1]. Increased cellular pools of RNA precursors are present at about the same time [3]. The increase in renal weight becomes significant $48-72 \mathrm{~h}$ after the STZ injection, and at the same time an increased protein/DNA ratio is seen, indicating cellular hypertrophy [1].

A renotropic function for insulin-like growth factor I (IGF-I) has recently been proposed in diabetic kidney growth [4-8]. The rapid renal hypertrophy occurring during the first days following induction of diabetes is preceded by a rise in renal IGF-I concentration, which reaches a peak after $24-48 \mathrm{~h}$ and then returns to basal levels after about 4 days $[4-6,8]$. Insulin treatment initiated immediately after the onset of hyperglycaemia in diabetic rats abolishes the increase in both kidney IGF-I and renal size, supporting the hypothesis that IGF-I may be responsible for the kidney growth $[4,6]$. When kidney IGF-I mRNA is measured during the initial diabetic renal growth [6] no changes are found during the first 4 days after onset of diabetes despite the transient IGF-I accumulation in the kidney, indicating that IGF-I may be taken up from the circulation rather than be locally produced.

The availability of recombinant human IGF-I enabled us to study the effects of systemic IGF-I infusion on renal enlargement, kidney IGF-I mRNA and immunoreactive 
kidney IGF-I content in diabetic rats at a time when kidney IGF-I accumulation had disappeared and the very rapid renal growth had abated. IGF-I infused diabetic animals were compared to $0.154 \mathrm{~mol} / 1 \mathrm{NaCl}$-infused nondiabetic and diabetic rats and to diabetic rats infused with insulin in equimolar concentrations to IGF-I.

\section{Materials and methods}

\section{Animals}

Male Sprague-Dawley rats (ALAB, Stockholm, Sweden) 7 weeks of age (mean body weight $201 \mathrm{~g}$ (range 180-212)) were kept in a room with a $12: 12 \mathrm{~h}$ artificial light cycle, temperature $21 \pm 2^{\circ} \mathrm{C}$ and humidity $55 \pm 2 \%$. The animals had free access to standard rat chow and tap water throughout the experiment. Diabetes was induced by i. v. injection of STZ ( $65 \mathrm{mg} / \mathrm{kg}$ body weight) in a tail vein; while control rats were injected with $0.154 \mathrm{~mol} / \mathrm{l} \mathrm{NaCl}$. The rats were considered diabetic if blood glucose levels exceeded $15 \mathrm{mmol} / \mathrm{l}$.

\section{Protocol}

After a diabetes duration of 5 days diabetic animals were infused for 4 days with insulin ( $35 \mathrm{nmol} /$ day) $(n=7)$, recombinant human IGF-I (KabiPharmacia Peptide Hormones, Stockholm, Sweden) $(36 \mathrm{nmol} /$ day) $(n=8)$ or $0.154 \mathrm{~mol} / 1 \mathrm{NaCl}(n=9)$ by using Alzet miniosmotic pumps (Alza Corp., Palo Alto, Calif., USA). The pumps were placed s.c. on the back under light ether anaesthesia. Nondiabetic control rats $(n=10)$ were infused with $0.154 \mathrm{~mol} / 1 \mathrm{NaCl}$. Blood glucose was measured twice daily ( 09.00 and 18.00 hours) in blood collected from the tip of the tail by using a hexokinase method (Gluco-quant, Boehringer-Mannheim GmbH, Mannheim, Grermany). Body weights were recorded daily at 10.00 hours. After the 4-day infusion period (9 days after induction of diabetes) the rats were killed by an overdose of ether, and the kidneys were rapidly removed, cleaned from fat and capsule, weighed and snap-frozen in liquid nitrogen.

\section{IGF-I extraction from kidney}

IGF-I extraction was performed according to D'Ercole et al. [9] as previously described [4-8]. Briefly, the kidneys were homogenized on ice in $1 \mathrm{~mol} / \mathrm{l}$ acetic acid ( $5 \mathrm{ml} / \mathrm{g}$ tissue) with an Ultra Turrax TD 25 and further disrupted using a Potter Elvehjelm homogenizer. The tissues were extracted twice, and after lyophilization the samples were re-dissolved in $40 \mathrm{mmol} / \mathrm{l}$ phosphate buffer $(\mathrm{pH} 8.0)$. Tissue extracts were kept at $-20^{\circ} \mathrm{C}$ until IGF-I assay was performed in diluted extracts. A linear relationship was found between biosynthetic IGF-I and the IGF-I immunoreactivity of kidney extracts at multiple concentrations, indicating antigen similarity and that no binding proteins or receptors from the extracts interfered in the immunoassay. Furthermore when biosynthetic IGF-I or an aliquot of the tissue extracts was gel-filtrated on Ultrogel (IBF) AcA 200, peaks in immunoreactive IGF-I occurred in the same fractions. When extracts from kidney were lyophilized and assayed in the presence of biosynthetic IGF-I the mean recovery of the added IGF-I was $101 \pm 4 \%(n=6)$ (mean \pm SEM). Finally, degradation of ${ }^{125}$ I-IGF-I was determined using chromatography and did not exceed $5 \%$ after $48 \mathrm{~h}$ incubation at $4^{\circ} \mathrm{C}$ in extracts as well as buffer media, excluding the possibility of extract proteases degrading the tracer.

When using this extraction procedure total tissue content of IGF-I is measured, including that contained in the extracellular space and the serum IGF-I entrapped in the tissue. When kidneys are carefully blotted and cleaned the amount of serum in tissues is usually down to a few percent of wet weight [9] and can therefore be ignored, providing that serum IGF-I concentrations in the experimental groups are comparable. However, in the present study comprising groups of animals with variable serum IGF-I levels a correction is necessary. In an additional study, four non-diabetic male rats (body weight around $200 \mathrm{~g}$ ) were injected i. v. with $8 \times 10^{6} \mathrm{cpm}$ of ${ }^{125} \mathrm{I}$-human albumin in $0.5 \mathrm{ml} 0.154 \mathrm{~mol} / \mathrm{l} \mathrm{NaCl}$. Blood samples drawn after 5,10 and 20 min showed identical isotope content after 10 and $20 \mathrm{~min}$, indicating equilibrium in serum. Twenty minutes after injecting the isotope the animals were bled by aortic puncture and kidneys cleaned and weighed as described above. Serum and whole blotted organs were counted and the volume of serum entrapped in $1 \mathrm{~g}$ of kidney calculated as follows:

$\frac{{ }^{125} \mathrm{I}-\text { albumin in kidney tissue }(\mathrm{cpm} / \mathrm{g})}{{ }^{125} \mathrm{I}-\text { albumin in serum }(\mathrm{cpm} / \mu \mathrm{l})}=\mu \mathrm{l}$ serum $/ \mathrm{g}$ kidney

The amount of serum in $1 \mathrm{~g}$ of kidney tissue amounted to: $21-35 \mu \mathrm{l} / \mathrm{g}$ $(n=4)$. The mean value of $30 \mu \mathrm{l} / \mathrm{g}$ was used to correct the total kidney IGF-I content measured. IGF-I was measured in kidney extracts by radioimmunoassay as previously described [4-8].

\section{Serum IGF-I determination}

Before being measured by radioimmunoassay serum IGF-I was separated from IGF-binding proteins by acidification in $2 \mathrm{~mol} / \mathrm{l}$ acetic acid at $4^{\circ} \mathrm{C}$ for $12 \mathrm{~h}$, and subsequent separation was performed on Sephadex G50 columns (Pharmacia Fine Chemicals, Uppsala, Sweden) equilibrated in $0.1 \mathrm{~mol} / \mathrm{l}$ acetic acid. The columns were calibrated with blue dextran, cytochrome $\mathrm{c}$ and ${ }^{125} \mathrm{I}-\mathrm{IGF}-\mathrm{I}$. Fractions containing free IGF-I were pooled, lyophilized and reconstructed in $40 \mathrm{mmol} / \mathrm{l}$ phosphate buffer ( $\mathrm{pH} 8.0$ ). The recovery when recombinant IGF-I was incubated with a serum sample, acidified, separated on columns, lyophilized and measured was $100 \pm 12 \% \quad(n=4)$ (mean \pm SEM). Less than $5 \%$ of ${ }^{125}$ I-IGF-I pre-incubated with serum at neutral $\mathrm{pH}$ for $24 \mathrm{~h}$ was still associated with binding proteins after acidification and chromatography.

\section{Preparation of total nucleic acid and solution-hybridisation of IGF-I $m R N A$}

Total nucleic acid (TNA) was prepared according to Durnam and Palmiter [10]. In short, the frozen kidneys were homogenized in a sodium dodecyl sulphate (SDS)-containing buffer with a polytron PT $1020350 \mathrm{D}$ (Kinematica GmbH, Luzern, Switzerland) for $8 \mathrm{~s}$. The samples were digested with proteinase $\mathrm{K}$ and extracted with phenol and chloroform. The TNA was precipitated by addition of ethanol and measured by spectrophotometry at $260 \mathrm{~nm}$, while the DNAcontent was measured by fluorimetry [11].

Levels of IGF-I mRNA were analysed using a $\left({ }^{35} \mathrm{~S}\right) \mathrm{UTP}$-labelled RNA probe. The probe was complementary to 153 basepairs in exon 3 (by analogy to the human gene) of the mouse IGF-gene as described previously [12]. This sequence has $92 \%$ homology with the corresponding rat sequence, and it detects the different forms of IGF mRNA which have been described in rat tissues [13]. The RNA probe, prepared according to the method of Melton [14], was hybridized to TNA samples at $70^{\circ} \mathrm{C}$ for $16 \mathrm{~h}$ as described by Mathews et al. [12]. Hybridization was performed in $40 \mu \mathrm{l}$ of $0.6 \mathrm{~mol} / \mathrm{l} \mathrm{NaCl}$, $20 \mathrm{mmol} / \mathrm{l}$ Tris- $\mathrm{HCl}$ (pH 7.5), $4 \mathrm{mmol} / \mathrm{l}$ EDTA, $0.1 \%$ (weight/volume) SDS, $7.5 \mathrm{mmol} / 1$ dithiothreitol (DTT), $25 \%$ (weight/volume) formamide and $10000 \mathrm{cpm}$ probe/incubation (specific activity; approximately $1.2 \times 10^{15} \mathrm{cpm} / \mathrm{g}$ probe). The samples were exposed to RNAses and the hybrids precipitated with $100 \mu \mathrm{l}$ of $6 \mathrm{~mol} / 1$ trichloroacetic acid, collected on glass microfibre filters and analysed in a liquid scintillation counter (LKB, 1217 Rackbeta, Turku, Finland). The radioactivity of the TNA samples was compared with that of a standard curve constructed from incubations with a rat liver TNA sample with a known amount of IGF-I mRNA. The level of IGF-I mRNA in the TNA standard sample was originally determined using known amounts of in vitro synthesized RNA complementary 

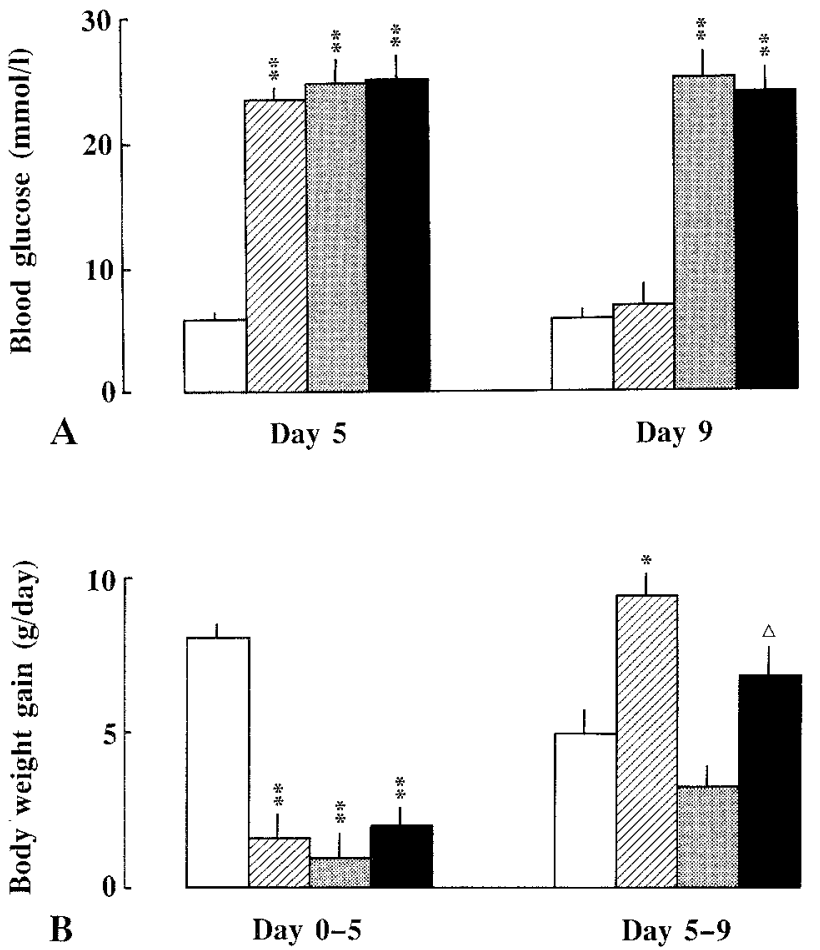

Fig.1. Blood glucose levels at day 5 and 9 (Fig. 1 A) and mean bodyweight gain in the period without treatment (day 0-5) and in the period with treatment (day 5-9) (Fig. 1 B) in $\square$ : non-diabetic control rats $(n=10)$, M: untreated diabetic rats $(n=9)$, $\square$ : diabetic rats treated with $35 \mathrm{nmol}$ insulin/day $(n=7)$ and $\square$ : diabetic rats treated with $36 \mathrm{nmol} \mathrm{IGF-I/day}(n=8)$. Insulin and insulin-like growth factor I (IGF-I) infusion was administered s. c. by means of miniosmotic pumps (Alzet, Alza Corp., Palo Alto, Calif., USA). Non-diabetic and diabetic control rats were infused with $0.154 \mathrm{~mol} / \mathrm{l} \mathrm{NaCl}$ as placebo treatment. ** $p<0.001$ between diabetic and non-diabetic animals and between untreated and IGF-I infused diabetic animals in comparison to insulin-treated and non-diabetic animals on day 9. $* p<0.05$ for insulin-treated diabetic animals compared to all other groups in the period day 5-9. $\Delta p<0.01$ between IGF-I treated and untreated diabetic animals in the period day 5-9. Values are mean \pm SEM

to the probe. A standard curve was included in each assay and the samples were analysed in triplicate. The intra- and the inter-assay coefficient of variation of the method was $22 \%$ and $20 \%$, respectively, when a sample with a very low concentration of IGF-I mRNA (13.1 pmol/l IGF-I mRNA) was analysed six times.

\section{Kidney RNA, DNA and protein determination}

RNA and DNA were separated by the Schmidt-Tannhäuser procedure performed according to Munro and Fleck [15]. DNA was determined with diphenylamine [16]. The protein concentration of the kidney homogenate was determined according to Lowry [17] with bovine albumin as standard.

\section{Statistical analysis}

Differences between groups were analysed by one-way analysis of variance in combination with the Bonferroni test for multiple comparisons and unpaired Student's $t$-test. $P$-values $<0.05$ were considered significant. All results are given as mean values \pm SEM.

\section{Results}

Metabolic parameters and body weight (Fig. 1)

All animals injected with STZ developed diabetes with blood glucose levels above $20 \mathrm{mmol} / \mathrm{l}$ after $24 \mathrm{~h}$. After 5 days of diabetes blood glucose levels remained at around $25 \mathrm{mmol} / \mathrm{l}$ in all three diabetic groups (Fig. 1 A). In response to initiation of insulin infusion on day 5 blood glucose levels returned to normal within 2 days and stabilized around $6 \mathrm{mmol} / 1$ from day 7 onwards with a value of $7.2 \pm 1.5 \mathrm{mmol} / \mathrm{l}$ on day 9 as shown in Figure $1 \mathrm{~A}$. By contrast, IGF-I infusion in diabetic animals did not affect blood glucose levels at any time, these animals having blood glucose concentrations around $25 \mathrm{mmol} / \mathrm{l}$ during the infusionperiod of 4 days, with a value of $23.9 \pm 1.7 \mathrm{mmol} / 1$ on day 9 as illustrated in Figure $1 \mathrm{~A}$. Non-diabetic rats and untreated diabetic animals maintained unchanged blood glucose levels around 6 and $25 \mathrm{mmol} / \mathrm{l}$, respectively, on days 5 and 9 (Fig. 1A).

Mean body-weight gain (expressed as g/day) in the four experimental groups in the period with no treatment (day 0-5) and period with treatment (day 5-9) are depicted in Figure $1 \mathrm{~B}$. During the first 5 days after induction of diabetes, all three diabetic groups had significantly lower body-weight gain (range: $0.8 \pm 0.9$ to $2.0 \pm 0.5 \mathrm{~g} /$ day) than non-diabetic control groups $(8.0 \pm 0.5 \mathrm{~g} / \mathrm{day}$, $p<0.01)$. In the period from day 5 to day 9 the $0.154 \mathrm{~mol} / \mathrm{l}$ $\mathrm{NaCl}$-infused diabetic rats had a body-weight gain of $3.3 \pm 0.8 \mathrm{~g} / \mathrm{day}$, while IGF-I treatment significantly increased the weight gain to $6.8 \pm 1.0 \mathrm{~g} /$ day $(p<0.01)$. Insulintreatment significantly increased body-weight gain $(9.3 \pm 0.6 \mathrm{~g} / \mathrm{day})$ as compared both to IGF-I treated and untreated diabetic rats $(p<0.05$ and $p<0.01$, respectively). $0.154 \mathrm{~mol} / \mathrm{/} \mathrm{NaCl}$-infused non-diabetic animals had a body-weight gain of $4.8 \pm 0.6 \mathrm{~g} /$ day from day 5 to day 9 , significantly different from that of insulin-treated diabetic animals $(p<0.05)$.

\section{Kidney weight (Table 1)}

Kidney weights in the four experimental groups on day 9 are shown in Table 1 . The kidney weight in the untreated diabetic rats was about $25 \%$ greater than the kidney weight in the non-diabetic rats $(p<0.01)$ (Table 1$)$. IGF-I infusion in diabetic animals caused a kidney-weight increase amounting to $36 \%$ in comparison to non-diabetic animals $(p<0.01)$, about $9 \%$ greater than the kidney weight obtained in $0.154 \mathrm{~mol} / \mathrm{l} \mathrm{NaCl}$-infused diabetic animals $(p<0.05)$. Insulin infusion in diabetic animals lowered the kidney weight in comparison to untreated diabetic animals $(p<0.05)$, and the kidney weight was not different from that of non-diabetic animals (Table 1 ). When the kidney weights were expressed as kidney weight/body weight $(\mathrm{KW} / \mathrm{BW})$ increased values were found in insulin-treated diabetic animals $(0.0042 \pm$ $0.0001)$, untreated diabetic animals $(0.0055 \pm 0.0001)$ as well as IGF-I infused diabetic animals $(0.0055 \pm 0.0001)$ in comparison to non-diabetic control animals $(0.0037 \pm$ 0.0001 , all $p<0.01)$. Insulin-treated diabetic animals had a 
Table 1. Kidney weight, kidney RNA/DNA, protein/DNA and DNA in the four experimental groups on day 9

\begin{tabular}{|c|c|c|c|c|}
\hline & $\begin{array}{l}\text { Kidney } \\
\text { weight } \\
(\mathrm{mg})\end{array}$ & $\begin{array}{l}\text { RNA/ } \\
\text { DNA } \\
(\mathrm{mg} / \mathrm{mg})\end{array}$ & $\begin{array}{l}\text { Protein/ } \\
\text { DNA } \\
(\mathrm{mg} / \mathrm{mg})\end{array}$ & $\begin{array}{l}\text { DNA } \\
(\mathrm{mg})\end{array}$ \\
\hline $\begin{array}{l}\text { Non-diabetic } \\
\text { control rats } \\
(n=10)\end{array}$ & $955 \pm 28$ & $1.24 \pm 0.01$ & $25.4 \pm 0.5$ & $3.17 \pm 0.09$ \\
\hline $\begin{array}{l}\text { Diabetic rats }+ \\
35 \mathrm{nmol} \text { insulin/day } \\
(n=7)\end{array}$ & $1030 \pm 32$ & $1.31 \pm 0.01^{\mathrm{a}}$ & $26.3 \pm 0.3$ & $3.18 \pm 0.07$ \\
\hline $\begin{array}{l}\text { Untreated } \\
\text { diabetic rats } \\
(n=9)\end{array}$ & $1190 \pm 34^{b}$ & $1.38 \pm 0.02^{b}$ & $27.8 \pm 0.3^{b}$ & $3.41 \pm 0.06^{b}$ \\
\hline $\begin{array}{l}\text { Diabetic rats }+ \\
36 \text { nmol IGF-I/day } \\
(n=8)\end{array}$ & $1303 \pm 36^{\mathrm{c}}$ & $1.48 \pm 0.02^{\circ}$ & $29.3 \pm 0.6^{\mathrm{c}}$ & $3.42 \pm 0.07^{\mathrm{d}}$ \\
\hline
\end{tabular}

Diabetic animals were left untreated during the first 5 days following induction of diabetes. After this period two diabetic groups were pump-infused with equimolar concentrations of insulin or IGF-I, while non-diabetic and diabetic control rats were infused with $0.154 \mathrm{~mol} / \mathrm{h} \mathrm{NaCl}$. ${ }^{a} p<0.01$, compared to non-diabetic control rats; b $<0.05$, compared to insulin-treated diabetic and non-diabetic rats; ${ }^{\circ} p<0.05$, compared to all other groups; ${ }^{\mathrm{d}} p<0.05$, compared to insulin-treated diabetic and non-diabetic rats. $n=$ number of animals in each group. Values are given as mean \pm SEM

Table 2. Kidney insulin-like growth factor I (IGF-I) mRNA, extractable kidney IGF-I and serum IGF-I in the four experimental groups on day 9

\begin{tabular}{|c|c|c|c|}
\hline & $\begin{array}{l}\text { Kidney IGF-I } \\
\text { mRNA } \\
\text { (molecules/cell) }\end{array}$ & $\begin{array}{l}\text { Kidney IGF-I } \\
\text { (ng/g kidney) }\end{array}$ & $\begin{array}{l}\text { Serum IGF-I } \\
(\mu \mathrm{g} / \mathrm{l})\end{array}$ \\
\hline $\begin{array}{l}\text { Non-diabetic } \\
\text { control rats } \\
(n=10)\end{array}$ & $1.47 \pm 0.13$ & $248 \pm 13$ & $698 \pm 19$ \\
\hline $\begin{array}{l}\text { Diabetic rats }+ \\
35 \text { nmol insulin/day } \\
(n=7)\end{array}$ & $1.47 \pm 0.15$ & $291 \pm 22$ & $645 \pm 51$ \\
\hline $\begin{array}{l}\text { Untreated } \\
\text { diabetic rats } \\
(n=9)\end{array}$ & $1.27 \pm 0.10$ & $230 \pm 14$ & $360 \pm 44^{b}$ \\
\hline $\begin{array}{l}\text { Diabetic rats }+ \\
36 \text { nmol IGF-I/day } \\
(n=8)\end{array}$ & $1.59 \pm 0.13$ & $466 \pm 29^{a}$ & $924 \pm 82^{a}$ \\
\hline
\end{tabular}

lower $\mathrm{KW} / \mathrm{BW}$ ratio in comparison to the two other diabetic groups $(p<0.01)$, but no difference in KW/BW was seen between untreated and IGF-I treated diabetic animals.

\section{Kidney RNA/DNA, kidney protein/DNA and kidney DNA (Table 1)}

In order to determine the biochemical changes in kidneys from untreated, IGF-I and insulin-treated diabetic animals, renal homogenates were analysed for content of protein, RNA and DNA. As shown in Table 1 the RNA/DNA ratio was increased in both insulin-treated and untreated diabetic animals by $6 \%$ and $11 \%$, respectively, as compared to non-diabetic control animals, the individual increases being different $(p<0.05)$. The IGF-I treated diabetic animals showed an increase in RNA/DNA of $19 \%$ in comparison to non-diabetic control animals and the increase amounted to $7 \%$ in comparison to untreated diabetic rats $(p<0.05)$ (Table 1$)$. Very similar changes were seen with respect to protein/DNA with increases in untreated and IGF-I treated diabetic animals of 9 and $15 \%$, respectively, in comparison to non-diabetic control animals, whilst no increase was seen in the insulintreated group (Table 1). The total kidney DNA content in untreated diabetic animals increased by $6 \%$ in comparison to non-diabetic control animals, while no increase in the DNA content in the insulin-treated diabetic group was seen. The IGF-I treated diabetic group showed an increase in DNA of $8 \%$, but this increase was not significantly higher than that of untreated diabetic rats.

\section{Kidney IGF-I $m R N A$ and extractable kidney IGF-I} (Table 2)

Kidney IGF-I mRNA levels (molecules/cell) and radioimmunoassayable kidney IGF-I (ng/g kidney tissue) in the four experimental groups are shown in Table 2. Kidney IGF-I mRNA levels were similar in the three diabetic groups with values comparable to those found in nondiabetic control rats. The kidney IGF-I concentrations in untreated and insulin-treated diabetic animals were similar, with levels comparable to those of non-diabetic control animals (Table 2). The renal IGF-I concentration in IGF-I treated diabetic animals was elevated by $88 \%$ in comparison to that of non-diabetic control animals $(p<0.01)$. The kidney IGF-I concentrations were all corrected for the contribution of serum IGF-I entrapped in the kidney tissue (see Materials and methods).

\section{Serum IGF-I (Table 2)}

Serum IGF-I levels $(\mu \mathrm{g} / 1)$ measured in all groups on day 9 are shown in Table 2. No differences were found in serum IGF-I between insulin-treated diabetic animals and nondiabetic control animals. Serum IGF-I was decreased by $44 \%$ in untreated diabetic animals in comparison to their insulin-treated counterparts $(p<0.001)$, while serum IGF-I levels in the IGF-I treated diabetic animals were elevated by $43 \%$ in comparison to insulin-treated control animals $(p<0.001)$ (Table 2$)$.

\section{Discussion}

The relevance of examining a possible effect of exogenous IGF-I infusion on renal growth in diabetic rats was determined by the previous finding that a transient IGF-I accumulation occurs in diabetic kidneys within the first 4 days after induction of diabetes before any measurable growth, 
suggesting that IGF-I is implicated in the initial diabetic growth phase as a renotropic factor [4-8].

The observations presented here demonstrate that insulin or IGF-I infusion in equimolar concentrations to diabetic rats has different effects on metabolic control and diabetic renal hypertrophy. Infusion of insulin to diabetic rats reduced blood glucose levels and renal size to normal and stimulated overall body growth. By contrast, infusion of IGF-I to diabetic rats had no effect on metabolic control but further stimulated the diabetic renal hypertrophy and body growth in comparison to untreated diabetic animals, thus maintaining the characteristic pathophysiological relationship between kidney and body weight. These results demonstrate that IGF-I administration initiated after 5 days of untreated diabetes with restoration of the initial high kidney IGF-I levels is capable of inducing renewed accelerated renal hypertrophy in diabetic animals.

Immunoreactive IGF-I has been demonstrated in many tissues and the presence of IGF-I mRNA in the kidney in this and other studies $[6,12,18]$ suggests that the kidney is capable of synthesizing IGF-I. In the present study, treatment with IGF-I increased kidney immunoreactive IGF-I, but did not significantly increase levels of kidney IGF-I mRNA. Interestingly, the accumulation of IGF-I in the early diabetic kidney growth phase takes place without changes in IGF-I mRNA levels [6]. These findings suggest that renal IGF-I accumulation as seen both after induction of experimental diabetes [4-8] and during exogenous IGF-I infusion to diabetic animals is due to increased uptake of circulating IGF-I or enhanced translatory mechanisms rather than increased local synthesis of IGF-I by the kidney. However, we cannot totally exclude that IGF-I mRNA may increase in specific segments of the nephron.

In the present study serum IGF-I levels were almost three times higher in IGF-I infused than in $0.154 \mathrm{~mol} / \mathrm{l}$ $\mathrm{NaCl}$-infused diabetic animals ( $924 \pm 82$ vs $360 \pm 44 \mu \mathrm{g} / \mathrm{l})$. Even supposing that all of the difference in serum IGF-I $(564 \mu \mathrm{g} / \mathrm{l})$ circulates in the free form and supposing that the same concentration is found in the extracellular space of the kidney (i. e. maximally $20 \%$ of the kidney weight), this could only explain approximately $122 \mathrm{ng} / \mathrm{g}$ of the difference $(236 \mathrm{ng} / \mathrm{g}$ ) in kidney IGF-I between IGF-I infused and untreated diabetic rats. It is likely therefore that infusion of exogenous IGF-I to diabetic animals in some way facilitates the entry of IGF-I into the kidney. This might happen through changes in kidney IGF-I receptor number or affinity or as a result of changes in kidney and serum IGF-binding proteins (IGFBP's).

Recent reports have demonstrated the existence of distinct receptors for IGF-I in rat renal glomeruli and tubules $[19,20]$. We recently showed that IGF-I receptor number and affinity in whole kidney homogenates obtained from hypertrophying diabetic kidneys, are unchanged within the first 7 days after induction of diabetes, giving no evidence that the initial increase in kidney IGF-I is due to changes at receptor level [21]. It is interesting, however, that in a recent study focusing on a slightly later phase ( 2 weeks after induction of diabetes) co-ordinated increases in kidney IGF-I receptor binding and IGF-I recep- tor mRNA expression were reported [22]. However, altered availability of circulating and tissue IGFBP's as previously described in experimental diabetes may also be responsible. Induction of STZ-diabetes causes a dramatic increase in hepatic mRNA levels of the two growth hormone $(\mathrm{GH})$-independent IGF binding proteins (IGFBP-1 and IGFBP-2) and circulating IGFBP-1 levels show a four-fold increase as early as 2-3 days after induction of diabetes [23-25]. In addition, circulating levels of the $\mathrm{GH}$ dependent IGF binding protein (IGFBP-3) are reported to be decreased in experimental diabetes in rats [26], in accordance with the suppressed GH release [27, 28]; interestingly, IGF-I infusion to diabetic rats has a stimulating effect on the decreased circulating IGFBP-3 levels [26]. The role of increased levels of IGFBP- 1 and -2 in untreated diabetes and of the partial restoration of IGFBP-3 with IGF-I administration for the increase in kidney IGF-I concentration and renal size is unknown and requires further investigation.

In accordance with previous studies we found that the diabetic kidney growth 9 days after induction of diabetes in untreated animals was due to both cellular hypertrophy and hyperplasia [1] assuming that RNA/DNA and protein/DNA ratios are indicators of the average cell size and that total kidney DNA content is an expression of the number of cells. Interestingly, the excess renal enlargement induced by IGF-I infusion appeared to be due predominantly to cellular hypertrophy i.e. similar to the early changes in diabetic kidney growth seen within the first 4 days of diabetes [1], which we believe is also caused by local kidney IGF-I accumulation [4-8]. These findings are consistent with the general view that IGF-I is a weak mitogen and further support the hypothesis that the early rise in kidney IGF-I in diabetic rats is indeed the main stimulus for renal growth.

In line with previous studies of the stimulatory effect of IGF-I on overall growth in diabetic animals, our results demonstrate a marked body-weight increase despite unaltered hyperglycaemia $[25,29]$. This growth-promoting effect is most likely mediated by IGF-I itself since diabetic rats are characterized by low levels of both insulin and $\mathrm{GH}$ $[27,28]$, two of the major regulators of circulating IGF-I levels. It is unlikely that exogenous IGF-I administration would partly restore $\mathrm{GH}$ secretion in diabetic rats as has been shown for insulin [27] since we and others [25, 29] have been unable to induce amelioration of the metabolic aberation by IGF-I and because intraventricular IGF-I infusion has been shown to suppress $\mathrm{GH}$ secretion, at least in non-diabetic rats [30]. In contrast, the growth-promoting effect of insulin in diabetic animals demonstrated in this and other studies is probably due to a combination of normalized metabolic control, GH secretion and serum IGF-I levels.

In conclusion, the present results show that IGF-I, when infused into diabetic animals, acts as a renotropic factor by further stimulating renal size at a point in time when the transient endogenous kidney IGF-I accumulation has disappeared and the initial rapid kidney growth has slackened. The biochemical changes in the diabetic kidney during IGF-I infusion bear similarities to the changes observed in the kidney within the first days of in- 
duction of diabetes, supporting the concept that the early kidney IGF-I accumulation may be the stimulus for kidney hypertrophy.

Acknowledgements. We are indebted to Ms. J.Hansen, Ms. R. Gidlöf and Ms. K. Nyborg for performing the technical assistance with their usual skill. We are also grateful to Dr. A. Skottner (KabiPharmacia Peptide Hormones, Stockholm, Sweden) for generously providing the recombinant human insulin-like growth factor I (hIGF-I), Dr. G. Norstedt for generously providing the insulin-like growth factor I (IGF-I) RNA probe, and Drs. L.E. Underwood and J.J. van Wyk and the National Hormone and Pituitary Program for the gifts of IGF-I antibody. The study was supported by grants from the Danish Diabetes Association, the Danish Medical Research Council, the Ruth König Petersen Foundation, the Novo Foundation and the Swedish Medical Research Council (4952).

\section{References}

1. Seyer-Hansen K (1983) Renal hypertrophy in experimental diabetes. Kidney Int 23: 643-646

2. Mogensen CE, Christensen CK (1984) Predicting diabetic nephropathy in insulin-dependent patients. N Engl J Med 311: 89-93

3. Cortes P, Lewin NW, Dumler F, Rubenstein AH, Verghese CP, Venkatachalam KK (1980) Uridine triphosphate and RNA synthesis during diabetes-induced kidney growth. Am J Physiol 238: E349-E357

4. Flyvbjerg A, Thorlacius-Ussing O, Næraa R, Ingerslev J, Ørskov $\mathrm{H}$ (1988) Kidney tissue somatomedin $\mathrm{C}$ and initial renal growth in diabetic and uninephrectomised rats. Diabetologia 31: 310314

5. Flyvbjerg A, Frystyk J, Thorlacius-Ussing O, Ørskov H (1989) Somatostatin analogue administration prevents increase in kidney somatomedin $\mathrm{C}$ and initial renal growth in diabetic and uninephrectomised rats. Diabetologia 32: 261-265

6. Flyvbjerg A, Bornfeldt KE, Arnqvist HJ, Ørskov H (1990) Kidney IGF-I mRNA in initial renal hypertrophy in experimental diabetes in rats. Diabetologia 33: 334-338

7. Flyvbjerg A, Ørskov H (1990) Kidney tissue insulin-like growth factor $I$ and initial renal growth in diabetic rats: relation to severity of diabetes. Acta Endocrinol (Copenh) 122:374-378

8. Flyvbjerg A, Frystyk J, Marshall SM (1990) Additive increase in kidney insulin-like growth factor I and initial renal enlargement in uninephrectomized-diabetic rats. Horm Metab Res 22: 516520

9. D'Ercole AJ, Stiles AD, Underwood LE (1984) Tissue concentration of somatomedin C: further evidence for multiple sites of synthesis and paracrine or autocrine mechanisms of action. Proc Natl Acad Sci USA 81: 935-939

10. Durnam DM, Palmiter RD (1983) A practical approach for quantitating specific mRNAs by solution hybridization. Anal Biochem 131: 385-393

11. Labarca C, Paigen K (1980) A simple, rapid and sensitive DNA assay procedure. Anal Biochem 102: $344-352$

12. Mathews LS, Norstedt G, Palmiter RD (1986) Regulation of insulin-like growth factor I gene expression by growth hormone. Proc Natl Acad Sci USA 83: 9343-9347

13. Shimatsu A, Rotwein P (1987) Mosaic evolution of the insulinlike growth factor I gene. J Biol Chem 262: 7894-7900

14. Melton DA, Krieg PA, Rebagliati MR, Maniatis T, Zinn K, Green MR (1984) Efficient in vitro synthesis of biologically active RNA and RNA hybridization probes from plasmids con- taining a bacteriophage SP6 promoter. Nucl Acids Res 12: 7035 7056

15. Munro HN, Fleck A (1966) The determination of nucleic acids. Methods Biochem Anal 14: 113-176

16.Burton K (1956) A study of the conditions and mechanism of the diphenylamine reaction for a calorimetric estimation of deoxyribonucleic acid. Biochem J 62: 315-323

17. Lowry OH, Osebrough NJ, Fara AL, Randall RL (1951) Porcine measurements with the folin phenol reagens. J Biol Chem 193: 165-175

18. Bornfeldt KE, Arnqvist HJ, Enberg B, Mathews LS, Norstedt G (1989) Regulation of insulin-like growth factor-I and growth hormone receptor gene expression by diabetes and nutritional state in rat tissues. J Endocrinol 122: 651-656

19. Arnqvist HJ, Ballerman BJ, King GL (1988) Receptors for and effects of insulin and IGF-I in rat glomerular mesangial cells. Am J Physiol 254: C411-C416

20. Pillion DJ, Haskell JF, Meezan E (1988) Distinct receptors for insulin-like growth factor I in rat renal glomeruli and tubules. Am J Physiol 255: E504-E512

21. Marshall SM, Flyvbjerg A, Frystyk J, Korsgaard L, Ørskov H (1991) Renal insulin-like growth factor I and growth hormone binding in experimental diabetes and after unilateral nephrectomy. Diabetologia 34: 632-639

22. Werner H, Shen-Orr Z, Stannard B, Burguera B, Roberts CT, LeRoith D (1990) Experimental diabetes increases insulin-like growth factor I and II receptor concentration and gene expression in kidney. Diabetes 39: 1490-1497

23. Ooi GT (1990) Insulin-like growth factor-binding proteins (IGFBPs): more than just 1, 2, 3. Mol Cell Endocrinol 71: C39$\mathrm{C} 43$

24. Unterman TG, Oehler DT, Becker RE (1989) Identification of a Type 1 insulin-like growth factor binding protein (IGFBP) in serum from rats with diabetes mellitus. Biochem Biophys Res Commun 163: 882-887

25. Böni-Schnetzler M, Binz K, Mary JL, Schmid C, Schwander J, Froesch ER (1989) Regulation of hepatic expression of IGF-1 and fetal IGF binding protein $\mathrm{mRNA}$ in streptozotocin-diabetic rats. FEBS Lett 251:253-256

26. Zapf J, Hauri C, Waldvogel M et al. (1989) Recombinant human insulin-like growth factor I induces its own specific carrier protein in hypophysectomized and diabetic rats. Proc Natl Acad Sci USA 86: $3813-3817$

27. Tannenbaum GS (1981) Growth hormone secretion dynamics in streptozocin diabetes: evidence of a role for endogenous somatostatin. Endocrinology 108: 76-82

28. Robinson ICAF, Clark RG, Carlsson LMS (1987) Insulin, IGF-I and growth in diabetic rats. Nature 326,549

29. Scheiwiller E, Guler HP, Merryweather J et al. (1986) Growth restoration of insulin-deficient diabetic rats by recombinant human insulin-like growth factor I. Nature 323: 169-171

30. Berelowitz M, Szabo M, Froman LA, Firestone S, Chu L, Hintz RL (1981) Somatomedin-C mediates growth hormone negative feedback by effects on both the hypothalamus and the pituitary. Science 212: 1279-1281

Received: 2 May 1991

and in revised form: 5 August 1991

Dr. A. Flyvbjerg

Institute of Experimental Clinical Research

Aarhus Kommunehospital

DK-8000 Aarhus C

Denmark 